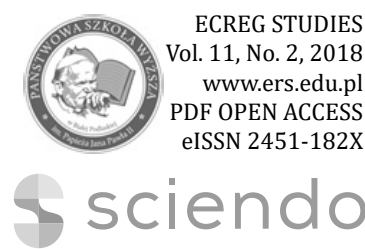

Authors' contribution/

Wkład autorów:

A. Zaplanowanie badań/

Study design

B. Zebranie danych/

Data collection

C. Analiza statystyczna/

Statistical analysis

D. Interpretacja danych/

Data interpretation

E. Przygotowanie tekstu/

Manuscript preparation

F. Opracowanie

piśmiennictwa/

Literature search

G. Pozyskanie funduszy/

Funds collection

\section{ECONOMIC AND REGIONAL STUDIES}

STUDIA EKONOMICZNE I REGIONALNE

ISSN 2083-3725

Volume 11, No. 2, 2018

\title{
THE USE OF PERSONAL COMPUTERS AND INTERNET NETWORKS BY PROFESSIONALLY ACTIVE PEOPLE WITH DISABILITIES LIVING IN RURAL AREAS
}

\section{WYKORZYSTANIE KOMPUTERÓW OSOBISTYCH I SIECI INTERNET PRZEZ CZYNNE ZAWODOWO OSOBY NIEPEŁNOSPRAWNE ZAMIESZKAŁE NA OBSZARACH WIEJSKICH}

\author{
Marek Kuźmicki ${ }^{(\mathrm{A}, \mathrm{B}, \mathrm{C}, \mathrm{D}, \mathrm{E}, \mathrm{F})}$, Jarosław Żbikowski ${ }^{(\mathrm{A}, \mathrm{B}, \mathrm{C}, \mathrm{E}, \mathrm{F})}$, \\ Agnieszka Siedlecka ${ }^{(A, B, C, E, F)}$
}

Pope John Paul II State School of Higher Education in Biała Podlaska Państwowa Szkoła Wyższa im. Papieża Jana Pawła II w Białej Podlaskiej

Kuźmicki M., Żbikowski J., Siedlecka A. (2018), The use of personal computers and Internet networks by professionally active people with disabilities living in rural areas/Wykorzystanie komputerów osobistych i sieci internet przez czynne zawodowo osoby niepełnosprawne zamieszkałe na obszarach wiejskich. Economic and Regional Studies, Vol. 11, No. 2, pp. 55-66. https://doi.org/10.2478/ers-2018-0015

\section{ORIGINAL ARTICLE}

\section{Summary}

JEL code: I14

Submitted:

February 2018

Accepted:

March 2018

Tables: 4

Figures: 3

References: 14

Subject and purpose of work: The aim of the article is to determine the level of accessibility of personal computers and the Internet and their use for distance work by professionally active persons with disabilities living in rural areas throughout Poland. Materials and methods: Surveys were carried out during the period from June 30,2010, to May 31, 2011, on a sample of 5,000 persons with disabilities, 1359 of whom, during the last 30 days of the survey, were gainfully employed they were professionally active. The area of research included randomly selected rural and urbanrural communes in sixteen provinces. Results: Personal computers and the Internet are most often used by the group of young people with disabilities and those who conduct their business activities in communes. Personal computers and the Internet are most often used by disabled persons with physical, sensory and complex disorders. Conclusions: It is necessary to intensify organisational, technical and legal activities and efforts that will contribute to a fuller and wider use of computers, the Internet and other assistive technology by people with disabilities.

Keywords: a person with disability, computer, Internet, availability, work

ORYGINALNY ARTYKUE NAUKOWY

Klasyfikacja JEL: I14

Zgłoszony:

Luty 2018

Zaakceptowany:

Marzec 2018

Tabele: 4

Rysunki: 2

Literatura: 14

\section{Streszczenie}

Przedmiot i cel pracy: Celem artykułu jest określenie poziomu dostępności do komputerów osobistych i Internetu oraz ich wykorzystania do pracy na odległość, przez osoby niepełnosprawne czynne zawodowo, zamieszkujące obszary wiejskie na terenie całej Polski. Materiały i metody: Badania ankietowe zostały zrealizowane w okresie od 30 czerwca 2010 roku do 31 maja 2011roku na próbie 5000 osób niepełnosprawnych, spośród których 1359 w ciągu ostatnich 30 dni od momentu badania wykonywały pracę zarobkową - były czynne zawodowo. Obszarem badań były losowo wybrane gminy wiejskie i miejsko-wiejskie w szesnastu województwach. Wyniki: Komputer i Internet są najchętniej wykorzystywane w grupie młodych osób niepełnosprawnych oraz tych, które prowadzą swoją działalność gospodarczą na terenie gmin. Komputer i Internet najczęściej wykorzystywane jest przez niepełnosprawnych z dysfunkcją fizyczną, sensoryczną i złożoną. Wnioski: Należy zintensyfikować działania i wysiłki organizacyjne, techniczne i prawne które przyczynią się do pełniejszego i szerszego wykorzystaniem komputerów i Internetu oraz innych urządzeń wspomagających przez osoby niepełnosprawne.

Słowa kluczowe: osoba niepełnosprawna, komputer, Internet, dostępność, praca

Address for correspondence/ Adres korespondencyjny: dr Marek Kuźmicki (ORCID 0000-0002-0581-9600), Państwowa Szkoła Wyższa im. Papieża Jana Pawła II w Białej Podlaskiej, Wydział Nauk Ekonomicznych i Technicznych, Zakład Finansów i Rachunkowości, ul. Sidorska 95/97, 21-500 Biała Podlaska, Poland; phone: +48 83 344-99-05; e-mail: marekbp7@gmail.com; doc. dr Jarosław Żbikowski, Wydział Nauk o Zdrowiu i Nauk Spełecznych, Zakład Turystyki; e-mail: j.zbikowski@dydaktyka.pswbp.pl; dr Agnieszka Siedlecka (ORCID 0000-0002-1853-0590), Wydział Nauk Ekonomicznych i Technicznych, Zakład Ekonomii, e-mail: a.siedlecka@dydaktyka.pswbp.pl

Journal indexed in/ Czasopismo indeksowane w: AgEcon Search, AGRO, BazEkon, Index Copernicus Journal Master List, ICV 2017: 100,00; Polish Ministry of Science and Higher Education 2016: 9 points / AgEcon Search, AGRO, BazEkon, Index Copernicus Journal Master List ICV 2017: 100,00; Ministerstwie Nauki i Szkolnictwa Wyższego 2016: 9 punktów. Copyright: (C) 2018 Pope John Paul II State School of Higher Education in Biała Podlaska, Marek Kuźmicki, Jarosław Żbikowski, Agnieszka Siedlecka. All articles are distributed under the terms of the Creative Commons Attribution-NonCommercial-ShareAlike 4.0 International (CC BY-NC-SA 4.0) License (http://creativecommons. org/licenses/by-nc-sa/4.0/), allowing third parties to copy and redistribute the material in any medium or format and to remix, transform, and build upon the material, provided the original work is properly cited and states its license. 


\section{Introduction}

Profession and work are important elements of our lives. Work is a source of income, organisation of time, a platform for social contacts, satisfaction, and self-fulfilment. Profession is a source of a sense of identity, a quality of life and identification with a social role (Ochonczenko 2004).

Work is a valuable asset. John Paul II emphasised its importance with his words "Work is a good thing for man - it is a good thing for his humanity - because through work man not only transforms nature, adapting it to his own needs, but he also achieves fulfilment as a human being and indeed, in a sense, becomes "more of a human being" (John Paul II 1987).

For people with disabilities, work is particularly important. It is not only a source of income. It supports the process of revalidation of such people. It contributes to the development of their personality, stimulates their activity. Work gives a person with disability an opportunity to improve his/her physical and mental functioning (Szczupał 2006). Professional work has an economic function and it prevents people with disabilities from isolation (Wołosiuk 2012). Problems that people with disabilities face concern first of all the choice of profession (or its change as a result of acquired disability), obtaining appropriate qualifications, preparation for work and employment, professional adaptation and retaining employment (Szczupał 2012).

According to the National Census of Population and Housing of 2011, the total number of people with disabilities at the end of March 2011 was approximately 4.7 million (exactly 4,697.0 thousand). Thus, the number of people with disabilities in Poland accounted for $12.2 \%$ of the country's population. The share of male participation among persons with disabilities was $46.1 \%$ compared to $53.9 \%$ for women (http://www.niepelnosprawni.gov.pl/index. php?c=page \&id=78\&print=1, access: $27 / 12 / 2017$ ) According to the LFS data, the number of people with disabilities aged 16 and more in 2016 was at the level of 3.2 million (exactly 3,207 thousand). After periodic stabilisation of the employment rate of people with disabilities in working age, oscillating around $22-23 \%$ in the years 2013-2015, in 2016 there was a rapid growth to $23.7 \%$. In 2016, the unemployment rate of people with disabilities in working age decreased to $11.6 \%$. Thus, the unemployment rate decreased by 1.4 percentage points compared to 2015 and by 4.5 percentage points compared to 2014. The results of the Labour Force Survey indicate that in 2016 the economic activity rate decreased slightly compared to 2015 (by 0.2 percentage point) reaching a value of $16.3 \%$ (http://www.niepelnosprawni.gov.pl/index.php?c = page $\&$ id $=80 \&$ print $=1$, access: $27 / 12 / 2017$ ).

Based on statistical data, it can be concluded that people with disabilities fall into the category of people at high risk of social exclusion. They are disadvantaged in the labour market, they

\section{Wstęp}

Istotnym elementem życia, każdej osoby jest praca i zawód. Praca jest źródłem dochodów, organizacji czasu, płaszczyzną kontaktów społecznych, zadowolenia, samorealizacji. Zawód to źródło poczucia tożsamości, poczucia jakości życia, identyfikacji z rolą społeczną (Ochonczenko 2004).

Praca to cenna wartość. Jej znaczenie podkreślił Jan Paweł II w słowach „Praca jest dobrem człowieka - dobrem jego człowieczeństwa - przez pracę bowiem człowiek nie tylko przekształca przyrodę, dostosowując ją do swoich potrzeb, ale także urzeczywistnia siebie jako człowiek, a także poniekąd bardziej staje się człowiekiem" (Jan Paweł II 1987).

Dla osób niepełnosprawnych praca ma szczególne znaczenie. Jest nie tylko obszarem pozyskiwania dochodu. Sprzyja procesowi rewalidacji tych osób. Przyczynia się do rozwoju osobowości, stymuluje aktywność. Praca sprawia, że osoba niepełnosprawna ma możliwość usprawnienia się pod względem fizycznym i psychicznym (Szczupał 2006). Praca zawodowa pełni funkcję ekonomiczną, jak również zapobiega izolacji społecznej osób niepełnosprawnych (Wołosiuk 2012). Problemy stojące przed osobami niepełnosprawnymi dotyczą przede wszystkim wyboru zawodu (bądź jego zmiany wskutek nabycia niepełnosprawności), uzyskania odpowiednich kwalifikacji oraz przygotowania do pracy i jej uzyskania, czyli zatrudnienia, adaptacji zawodowej i utrzymania się w zatrudnieniu (Szczupał 2012).

Według wyników Narodowego Spisu Powszechnego Ludności i Mieszkań z 2011 roku liczba osób niepełnosprawnych ogółem wynosiła na koniec marca 2011 r. niemal 4,7 mln (dokładnie 4 697,0 tys.). Tym samym liczba osób niepełnosprawnych w Polsce stanowiła 12,2\% ludności kraju. Udział mężczyzn wśród osób niepełnosprawnych wynosił $46,1 \%$ wobec $53,9 \%$ kobiet (http://www.niepelnosprawni.gov.pl/index. php?c=page\&id=78\&print=1, dostep: 27.12.2017). Zgodnie z danymi BAEL liczba osób niepełnosprawnych w wieku 16 lat i więcej w 2016 roku kształtowała się na poziomie 3,2 mln osób (dokładnie 3207 tys.). Po okresowej stabilizacji wartości wskaźnika zatrudnienia osób niepełnosprawnych $w$ wieku produkcyjnym, oscylujacej w granicach $22-23 \%$ na przestrzeni lat 2013-2015, w roku 2016 nastąpił jego gwałtowny wzrost do 23,7\%.W roku 2016 zanotowano obniżenie się poziomu stopy bezrobocia osób niepełnosprawnych $w$ wieku produkcyjnym do $11,6 \%$. Tym samym stopa bezrobocia obniżyła się o 1,4 punktów procentowych w stosunku do roku 2015 oraz o 4,5 punktów procentowych w stosunku do roku 2014. Wyniki Badania Aktywności Ekonomicznej Ludności wskazują, że w 2016 roku współczynnik aktywności zawodowej spadł nieznacznie w stosunku do roku 2015 (o 0,2 pkt. proc.) osiągając wartość 16,3\% (http://www.niepelnosprawni.gov.pl /index.php?c=page\&id=80\&print=1, dostęp: 27.12.2017).

Bazując na danych statystycznych można stwierdzić, że osoby z niepełnosprawnością należą do kategorii osób o dużym ryzyku wykluczenia społecznego. Cechuje je niekorzystne położenie na rynku pracy, 
face employment discrimination and they are characterised by low professional activity.

Disability generally constitutes a major obstacle while undertaking economic activity. Most people with disabilities in Poland are professionally inactive. Persons with disabilities first exit the labour market and they are the last ones to enter it, therefore they are at risk of poverty (Garbat 2013). Many people in this group want to work and can work, but they remain outside the labour market through no fault of their own. Should real opportunities arise, a large part of today's professionally inactive persons would certainly take up a job (Wójcik 2008).

The development of IT systems contributes to an increase in the professional activity of people with disabilities. Teleworking is a new form of employment offered to people with disabilities, it has not been very popular in Poland so far. This form of activity does not ensure full integration of disabled persons, but it allows them to earn income, develop their sense of self-worth and regain social position (MagnuszewskaOtulak 2009). A characteristic feature of teleworking is that there is no central working place for the employer, employee and a potential customer. The work is carried out at a distance (outside the traditional workplace), and the results of the work are transferred to the employer by means of electronic communication. Teleworking is also referred to as: "remote work", "work at a distance", "e-work" the terms are used interchangeably (Olszewski et al. 2012). The necessary condition for professional activation in the form of teleworking is the use of a personal computer.

The aim of the article is to determine the level of accessibility of personal computers and the Internet and their use for distance work by professionally active persons with disabilities living in rural areas throughout Poland.

\section{Methodology of the research ${ }^{1}$}

Materials used to prepare this paper were based on nationwide survey carried out from June 30, 2010 to May 31, 2011 by employees of the Pope John Paul II State School of Higher Education in Biała Podlaska as part of the research project "Determinants of the professional activity of persons with disabilities living in rural areas". The project implemented in the years 2008-2012 was financed by PFRON. The research area covered rural and urban-rural communes of sixteen Polish provinces, where the interviewers conducted research among 5,000 disabled people, including 1359 respondents who were gainfully employed during the last 30 days from the moment of the research. The selection of the research sample was carried out using a randomised layer selection method. The layers of the research included:province, poviat, commune, sex, age, marital status, education, type of disability. The sampling

\footnotetext{
1 Research was carried out as part of the project financed by PFRON in the years 2008 - 2012 as a research project: "Determinants of the professional activity of persons with disabilities living in rural areas". Agreement No. 3 / 4WRP / B / 08
}

dyskryminacja w zatrudnieniu oraz niska aktywność zawodowa.

Niepełnosprawność stanowi na ogół istotną przeszkodę w podejmowaniu aktywności ekonomicznej. Większość osób niepełnosprawnych mieszkających w Polsce jest bierna zawodowo. Osoby z niepełnosprawnością pierwsze „wypadają” z rynku pracy i ostatnie wracają, przez co są zagrożone ubóstwem (Garbat 2013). Istnieje wiele osób z tej grupy, które chcą i mogą pracować, a pozostają nie ze swej winy poza rynkiem pracy. Gdyby tylko pojawiły się ku temu rzeczywiste możliwości, duża część dziś biernych zawodowo z pewnością podjęłaby pracę (Wójcik 2008).

Zwiększeniu aktywności zawodowej osób niepełnosprawnych sprzyja rozwój technik teleinformatycznych. Nowatorską formą zatrudnienia osób niepełnosprawnych, w niewystarczającym stopniu wykorzystywaną do tej pory w Polsce jest telepraca. To forma aktywności, która wprawdzie nie zapewnia pełnej integracji, ale umożliwia uzyskanie dochodu, budowanie poczucia własnej wartości i pozycji społecznej (Magnuszewska-Otulak 2009). Cechą charakterystyczną telepracy jest brak jedności miejsca pracodawcy, pracownika i ewentualnego klienta. Praca jest wykonywana na odległość (poza tradycyjnym miejscem pracy), a jej wyniki są przekazywane pracodawcy drogą elektroniczną. Telepracę określa się zamiennymi pojęciami: „praca zdalna”, “praca na odległość", "e-praca" (Olszewski i in. 2012). Warunkiem aktywizacji zawodowej w formie telepracy jest korzystanie z komputera osobistego.

Celem artykułu jest określenie poziomu dostępności do komputerów osobistych i Internetu oraz ich wykorzystania do pracy na odległość przez osoby niepełnosprawne czynne zawodowo zamieszkujące obszary wiejskie na terenie całej Polski.

\section{Metodyka badań $^{1}$}

Materiał do niniejszego opracowania powstał w wyniku zrealizowanych od 30 czerwca 2010 roku do 31 maja 2011 roku przez pracowników Państwowej Szkoły Wyższej im. Papieża Jana Pawła II w Białej Podlaskiej ogólnopolskich badań w ramach projektu badawczego „Determinanty aktywności zawodowej osób niepełnosprawnych zamieszkałych na obszarach wiejskich". Projekt zrealizowany w latach 2008-2012 został sfinansowany ze środków PFRON. Teren badań objął gminy wiejskie i miejsko-wiejskie szesnastu województw Polski, gdzie ankieterzy dotarli do 5000 osób niepełnosprawnych, w tym 1359 respondentów, którzy w ciągu ostatnich 30 dni od momentu badania wykonywali pracę zarobkową. Doboru jednostek do próby badawczej dokonano przy pomocy metody doboru losowo - warstwowego. W badaniach warstwami były: województwo, powiat, gmina, płeć, wiek, stan cywilny, wykształcenie, rodzaj niepełnosprawności.

\footnotetext{
1 Badania realizowane $\mathrm{w}$ ramach projektu finansowanego przez PFRON w latach 2008 - 2012 jako projekt badawczy: „Determinanty aktywności zawodowej osób niepełnosprawnych zamieszkałych na obszarach wiejskich". Umowa nr 3/4WRP/B/08
} 
frame consisted of databases of Voivodship Disability Evaluation Boards, District Family Assistance Centres, Workshops of Occupational Therapy and/or database of the Office of Government Representative on Disabled People. The determination of the size of research sample in particular provinces was based on the number of disabled people in the general population according to the results of the National Census of 2002. The structure of the research sample is presented in Table 1.
Operatem losowym były bazy danych Wojewódzkich Zespołów ds. Orzekania o Niepełnosprawności, Powiatowych Centrów Pomocy Rodzinie, Warsztatów Terapii Zajęciowej lub/i bazy danych Biura Pełnomocnika Rządu ds. osób niepełnosprawnych. Ustalając liczebność próby badawczej w poszczególnych województwach bazowano na ilości osób niepełnosprawnych w populacji generalnej zgodnej z wynikami Narodowego Spisu Powszechnego z 2002 roku. Strukturę próby badawczej przedstawia tabela 1 .

Table 1. Structure of the research sample

Tabela 1. Struktura próby badawczej

\begin{tabular}{|c|c|c|c|c|c|c|}
\hline \multirow[b]{2}{*}{ Sex / Płeć } & \multicolumn{3}{|c|}{ Women / Kobiety } & \multicolumn{3}{|c|}{ Men / Mężczyźni } \\
\hline & \multicolumn{3}{|c|}{$\begin{array}{l}n=679 \\
(49.96 \%)\end{array}$} & \multicolumn{3}{|c|}{$\begin{array}{l}n=680 \\
(50.04 \%)\end{array}$} \\
\hline \multirow[b]{2}{*}{ Age / Wiek } & \multicolumn{2}{|c|}{$<45$ years old / lat } & \multicolumn{2}{|c|}{ 45-54 years old / lat } & \multicolumn{2}{|c|}{$\geq 55$ years old / lat } \\
\hline & \multicolumn{2}{|l|}{$\begin{array}{c}\mathrm{n}=171 \\
(12.58 \%)\end{array}$} & \multicolumn{2}{|c|}{$\begin{array}{c}\mathrm{n}=848 \\
(62.40 \%)\end{array}$} & \multicolumn{2}{|r|}{$\begin{array}{c}\mathrm{n}=340 \\
(25.02 \%)\end{array}$} \\
\hline \multirow{2}{*}{$\begin{array}{l}\text { Marital status / } \\
\text { Stan cywilny }\end{array}$} & \multicolumn{2}{|c|}{ Single / Kawaler/Panna } & \multicolumn{2}{|c|}{ Married / Żonaty/Zamężna } & & Other / Inny \\
\hline & \multicolumn{2}{|l|}{$\begin{array}{c}n=277 \\
(20.38 \%)\end{array}$} & \multicolumn{2}{|c|}{$\begin{array}{c}\mathrm{n}=946 \\
(69.61 \%)\end{array}$} & & $\begin{array}{c}n=136 \\
(10.01 \%)\end{array}$ \\
\hline \multirow[t]{2}{*}{ Education / Wykształcenie } & $\begin{array}{c}\text { Primary } \\
\text { Lower secondary / } \\
\text { Podstawowe/gim- } \\
\text { nazjalne } \\
\end{array}$ & Zas & $\begin{array}{l}\text { econdary } \\
\text { ocational / } \\
\text { nicze/Średnie- } \\
\text { tawodowe }\end{array}$ & \multicolumn{2}{|c|}{ 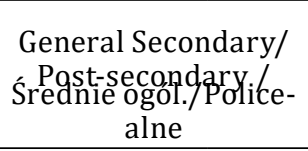 } & Higher / Wyższe \\
\hline & $\begin{array}{c}\mathrm{n}=196 \\
(14.44 \%)\end{array}$ & \multicolumn{2}{|r|}{$\begin{array}{c}n=823 \\
(60.65 \%)\end{array}$} & \multicolumn{2}{|c|}{$\begin{array}{c}n=186 \\
(13.71 \%)\end{array}$} & $\begin{array}{c}\mathrm{n}=152 \\
(11.20 \%)\end{array}$ \\
\hline \multirow{2}{*}{$\begin{array}{c}\text { Type of disability / } \\
\text { Rodzaj niepełnosprawności }\end{array}$} & $\begin{array}{l}\text { Psychological / } \\
\text { Psychiczna }\end{array}$ & \multicolumn{2}{|c|}{$\begin{array}{c}\text { Sensory / } \\
\text { Sensoryczna }\end{array}$} & \multicolumn{2}{|c|}{ Physical / Fizyczna } & Complex / Złożona \\
\hline & $\begin{array}{c}\mathrm{n}=157 \\
(11.55 \%)\end{array}$ & \multicolumn{2}{|r|}{$\begin{array}{c}\mathrm{n}=138 \\
(10.15 \%)\end{array}$} & \multicolumn{2}{|c|}{$\begin{array}{c}\mathrm{n}=713 \\
(52.47 \%)\end{array}$} & $\begin{array}{c}\mathrm{n}=351 \\
(25.83 \%)\end{array}$ \\
\hline
\end{tabular}

Source: elaboration based on own research.

Źródło: opracowanie na podstawie badań własnych.

Statistical analysis was based on the STATISTICA v. 7.1 program. Pearson's Chi-Square test of independence was applied to examine the significant differences between the studied groups. The significance level $p=0.05$ was used.

\section{The results of the research}

During the research, the respondents described the place of their current employment. Over one third of the research participants - 34.54\% were employed in private enterprises. Almost every fifth respondent - $19.53 \%$ worked in a sheltered workshop. A significant percentage of respondents - $15.69 \%$ were members of personnel of stateowned enterprises. $6.33 \%$ of respondents worked in agricultural farms. Business activity was conducted by $4.07 \%$ of the respondents. The results of the research are presented in Figure 1.

The results of the research indicate that more than a half of professionally active people with disabilities participating in the study were using personal computer $-60.65 \%$. The vast majority of respondents in this group - $88.63 \%$ were also the Internet users. The Internet was used for professional purposes only by $32.55 \%$ of the respondents. The results of the research are presented in Table 2.
Analizę statystyczną przeprowadzoną w oparciu o program STATISTICA v. 7.1. W celu zbadania istotności różnic, pomiędzy badanymi grupami, zastosowano test niezależności dla zmiennych nominalnych Chi kwadrat Pearsona. Przyjęto poziom istotności p=0,05.

\section{Wyniki badań}

W czasie badań respondenci określili miejsce swojego aktualnego zatrudnienia. Ponad jedna trzecia uczestników badania - 34,54\% była pracownikami przedsiębiorstw prywatnych. Mniej więcej, co piąty badany - $19,53 \%$ pracował w zakładzie pracy chronionej. Znaczny odsetek respondentów - 15,69\% wchodził w skład kadr przedsiębiorstw państwowych. W gospodarstwach rolnych zatrudnionych było $6,33 \%$ uczestników badania. Własną działalność gospodarczą prowadziło 4,07\% z nich. Wyniki badań przedstawia rysunek 1.

Wyniki badań wskazują, że ponad połowa czynnych zawodowo osób niepełnosprawnych uczestniczących w badaniu korzystało z komputera $-60,65 \%$. Zdecydowana większość w tej grupie - 88,63\% korzystała także z Internetu. Internet został wykorzystany do celów zawodowych tylko przez 32,55\% użytkowników tej Sieci. Wyniki badań przedstawia tabela 2. 


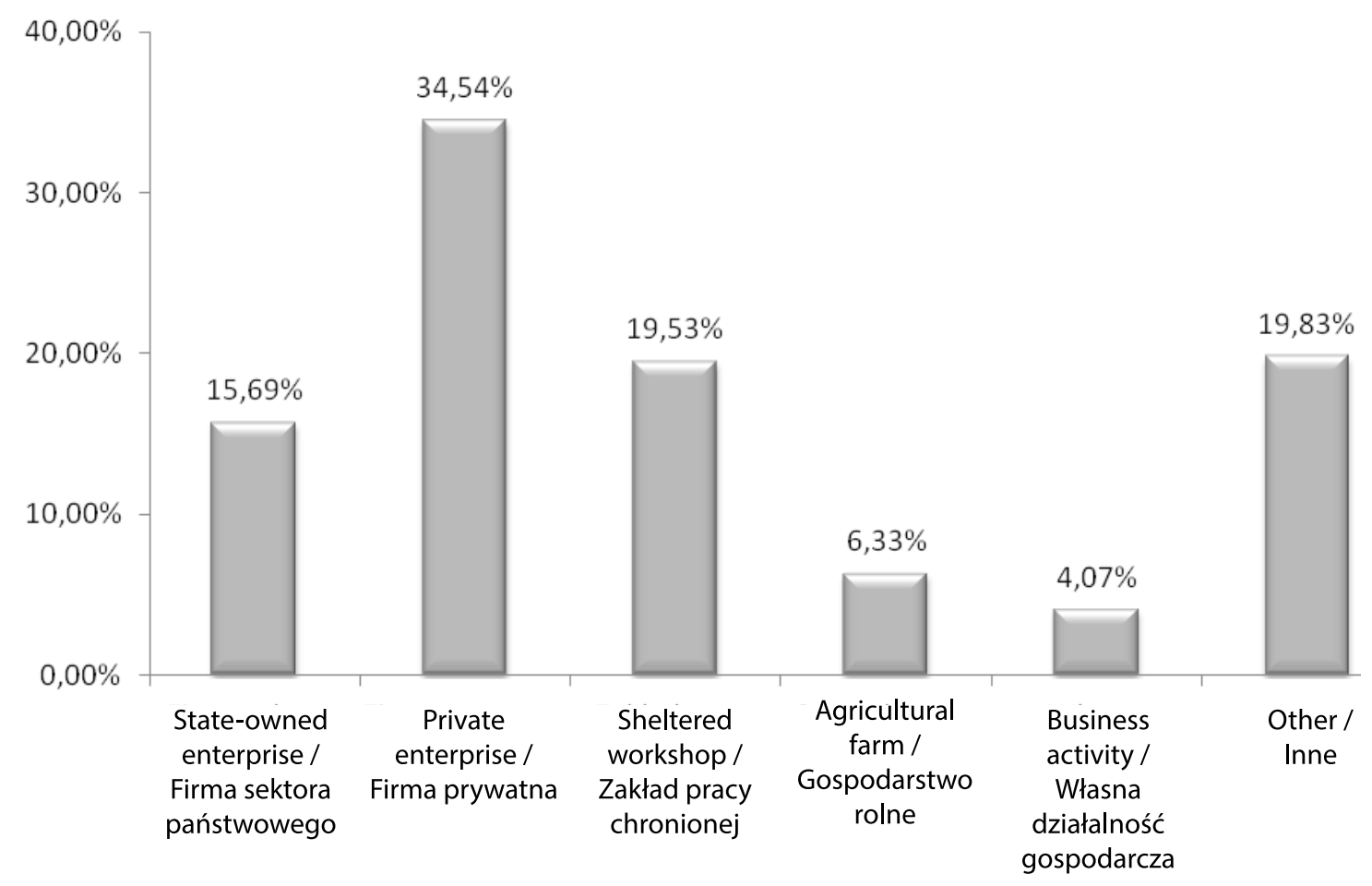

Figure 1. Place of employment of respondents Rysunek 1. Miejsce zatrudnienia respondentów Source: elaboration based on own research.

Źródło: opracowanie na podstawie badań własnych.

Table 2. The use of computers and the Internet by professionally active persons with disabilities Tabela 2. Wykorzystanie komputerów i Internetu przez czynne zawodowo osoby niepełnosprawne

\begin{tabular}{|c|c|c|c|c|}
\hline \multirow{2}{*}{$\begin{array}{c}\text { Do you use a computer? / } \\
\text { Czy korzysta Pan/i z komputera? }\end{array}$} & \multicolumn{3}{|c|}{ Yes / Tak } & No / Nie \\
\hline & \multicolumn{3}{|c|}{$\begin{array}{l}823 \text { persons } \\
(60.65 \%)\end{array}$} & $\begin{array}{c}\text { 534 persons } \\
(39.35 \%)\end{array}$ \\
\hline \multirow{2}{*}{$\begin{array}{c}\text { Do you use the Internet? / } \\
\text { Czy korzysta Pan/i z Internetu? }\end{array}$} & \multicolumn{2}{|c|}{ Yes / Tak } & No / Nie & \\
\hline & \multicolumn{2}{|c|}{$\begin{array}{c}725 \text { persons / osób } \\
(88.63 \%)\end{array}$} & $\begin{array}{c}93 \text { persons / osób } \\
(11.37 \%)\end{array}$ & \\
\hline \multirow{2}{*}{$\begin{array}{l}\text { Do you use the Internet for } \\
\text { professional purposes?/ } \\
\text { Czy korzysta Pan/i z Internetu w celu } \\
\text { wykonywania pracy? }\end{array}$} & Yes / Tak & No / Nie & & \\
\hline & $\begin{array}{c}236 \text { persons } \\
\text { / osób } \\
(32.55 \%)\end{array}$ & $\begin{array}{c}489 \text { persons } \\
\text { / osób } \\
(67.45 \%)\end{array}$ & & \\
\hline
\end{tabular}

Source: elaboration based on own research.

Źródło: opracowanie na podstawie badań własnych.

Among the respondents, the percentage of women using computers was higher than the percentage of men $-63.2 \%$. For men it was $-58.1 \%$. Computers are mainly used by young people. In the age group up to 45 years old, computers are used by 4 out of 5 disabled people. Only every fifth person has never used a computer. In the age group 45-54 years old, $61.8 \%$ of respondents declared that they were using computers. This percentage was lower In the age group $55+$. It was $48.1 \%$. There is a similar percentage of the disabled persons using computers who are married $-61.7 \%$ and who are single $-62.6 \%$. The percentage is clearly lower in case off widows and widowers - 44.9\%. The level of education affects the number of the disabled persons using computers. In case of the respondents with higher education, almost all of them use computers - $95.4 \%$.
Wśród badanych większy odsetek kobiet niż mężczyzn korzystał z komputerów - 63,2\%. W przypadku mężczyzn wynosił on - 58,1\%. Komputerami posługują się głównie osoby młode. W grupie wiekowej do 45 lat komputery wykorzystuje 4 na 5 osób niepełnosprawnych. Tylko co piata osoba nie ma styczności z komputerem. W grupie wiekowej 45-54 lata korzystanie z komputerów zadeklarowało $61,8 \%$ badanych. Odsetek ten był niższy w kategorii wiekowej 55 lat i więcej. Wynosił 48,1\%. Zbliżony odsetek osób niepełnosprawnych korzysta z komputerów w przypadku respondentów będących $\mathrm{w}$ związku małżeńskim $-61,7 \%$ oraz żyjących jako single $-62,6 \%$. Jest on wyraźnie mniejszy w przypadku wdów i wdowców - 44,9\%. Poziom wykształcenia ma wpływ na liczbę osób niepełnosprawnych korzystających z komputerów. W przypadku respondentów z wykształceniem 
In case of the group of people with secondary and post-secondary education, this percentage is $75.3 \%$. More than half of respondents with basic vocational education and secondary vocational education use computers - $58.8 \%$. This percentage is clearly lower among people with primary and lower secondary education - $27.6 \%$. The highest percentage of respondents using computers has been recorded among people with physical and sensory disabilities - $64.6 \%$ and $64.5 \%$. This percentage is slightly lower in case of computer users recorded among respondents with complex (57.7\%) and mental disability (45.9\%). Computers are most often used by the disabled persons employed in stateowned enterprises - $76 \%$ of all people employed in the public sector, and self-employed $-74.1 \%$ of all persons conducting business activity. Percentage of the respondents using computers in other places of employment is lower - private companies - 59.7\%, sheltered workshops - $54.1 \%$, agricultural farms $48.8 \%$. In the group of people satisfied with their jobs, $68.6 \%$ were those using computers. This percentage in the group of people rather satisfied with their job was $63.0 \%$. It was slightly lower among people moderately satisfied $-47.3 \%$, fairly dissatisfied $-34.9 \%$ and totally dissatisfied with their job - 9.1\%. The common use of computers by the disabled persons living in rural and urbanrural communes with respect to gender, age, marital status, education, type of disability, place of employment, job satisfaction, taking into account statistical differences between the features is presented in Figure 2.

During the research, the group of respondents using computers and the resources and functions of the Internet was determined. Women with disabilities living in rural areas use the Internet more often than men. $89.2 \%$ of women uses the Internet. For men it is $88.0 \%$. The Internet is equally popular among respondents of all age groups. Among people up to the age of 45 , the Internet is used by $91.2 \%$ of computer users, in the age group $45-54-87.5 \%$, and in the age group $55+$ it is $-90.1 \%$. Regardless of marital status, the vast majority of the respondents uses the Internet. In the group of singles $-83.6 \%$ of the respondents, among married people $-90.6 \%$ of the respondents, among widows and widowers $-83.3 \%$ of the respondents. Almost all of the disabled persons with higher education using computer also use computer network - 97.2\%. Among people with general and post-secondary and secondary education, the percentage is $93.6 \%$, the basic and secondary vocational education $87.3 \%$, and in the group of people with primary and lower secondary education - $64.2 \%$. The highest percentage of computer users using the Internet is among people with physical disability $-91.3 \%$ and with complex disability $-88.0 \%$. Among people with mental disability, it is $70.4 \%$. Taking into account the place of employment, it can be observed that the Internet is used by the largest number of computer users who conduct their own business activities - 92.5\%, who work in a state-owned enterprises wyższym prawie wszyscy z niego korzystają - 95,4\%. W grupie osób z wykształceniem średnim i policealnym odsetek ten wynosi 75,3\%. Z komputera korzysta ponad połowa - 58,8\% respondentów z wykształceniem zasadniczym i średnim zawodowym. Odsetek ten jest wyraźnie niższy wśród osób z wykształceniem podstawowym i gimnazjalnym - 27,6\%. Największy odsetek badanych korzysta z komputerów wśród osób z niepełnosprawnością fizyczną i sensoryczną - 64,6\% i $64,5 \%$. Nieco mniejszy jest udział korzystających z komputerów wśród respondentów z niepełnosprawnością złożoną - 57,7\% i psychiczną 45,9\%. Z komputerów najczęściej korzystają osoby niepełnosprawne zatrudnione $\mathrm{w}$ przedsiębiorstwach państwowych - 76\% z wszystkich osób zatrudnionych w sektorze publicznym oraz prowadzące własną działalność gospodarczą - 74,1\% wszystkich osób prowadzących działalność gospodarczą. Odsetek respondentów korzystających z komputera $w$ innych miejscach zatrudnienia jest niższy - firmy prywatne - 59,7\%, zakłady pracy chronionej - 54,1\%, gospodarstwa rolne $48,8 \%$. $\mathrm{W}$ grupie osób zdecydowanie zadowolonych z pracy aż 68,6\% stanowiły te, które korzystały z komputera. Odsetek ten w grupie osób raczej zadowolonych z pracy wynosił $63,0 \%$. Był nieco niższy - 47,3\% wśród umiarkowanie zadowolonych z pracy, raczej niezadowolonych z pracy - 34,9\% i zdecydowanie niezadowolonych z pracy - 9,1\%. Powszechność wykorzystania komputerów przez osoby niepełnosprawne zamieszkujące gminy wiejskie i miejsko-wiejskie z uwagi na płeć, wiek, stan cywilny, wykształcenie, rodzaj niepełnosprawności, miejsce zatrudnienia, zadowolenie z pracy z uwzględnieniem różnic statystycznych między cechami przedstawia rysunek 2 .

W trakcie badań określono jaka część respondentów korzystająca z komputerów wykorzystuje zasoby i funkcje Internetu. Kobiety niepełnosprawne zamieszkujące obszary wiejskie nieco częściej niż mężczyźni korzystają z Internetu. Robi to 89,2\% kobiet korzystających z komputera. W przypadku mężczyzn odsetek ten wynosi 88,0\%. Internet jest wśród respondentów jednakowo popularny we wszystkich grupach wiekowych. Wśród osób do 45 roku życia włącznie korzysta z niego 91,2\% użytkowników komputerów, w kategorii wiekowej 45-54 lata 87,5\%, a w powyżej i włącznie 55 lat $90,1 \%$. Niezależnie od stanu cywilnego zdecydowana większość respondentów wykorzystuje Internet. W grupie singli robi to $83,6 \%$ badanych, osób w związkach małżeńskich $90,6 \%$ badanych, wdów i wdowców 83,3\% badanych. Prawie wszystkie osoby niepełnosprawne używające komputera z wykształceniem wyższym korzystają z sieci komputerowej 97,2\%. Wśród osób z wykształceniem średnim ogólnokształcącym i policealnym odsetek ten wynosi 93,6\%, zasadniczym i średnim zawodowym $87,3 \%$, a w grupie osób z wykształceniem podstawowym i gimnazjalnym $64,2 \%$. Z Internetu korzysta największy odsetek użytkowników komputerów z niepełnosprawnością fizyczną - 91,3\% i złożoną 88,0\%. Wśród osób z niepełnosprawnością psychiczną udział ten stanowi 70,4\%. Biorąc pod uwagę miejsce zatrudnienia można zauważyć, że z Internetu korzysta najwięcej użytkowników komputerów z grupy, która prowadzi własną działal- 
$0,0 \% \quad 20,0 \% \quad 40,0 \% \quad 60,0 \% \quad 80,0 \% \quad 100,0 \%$

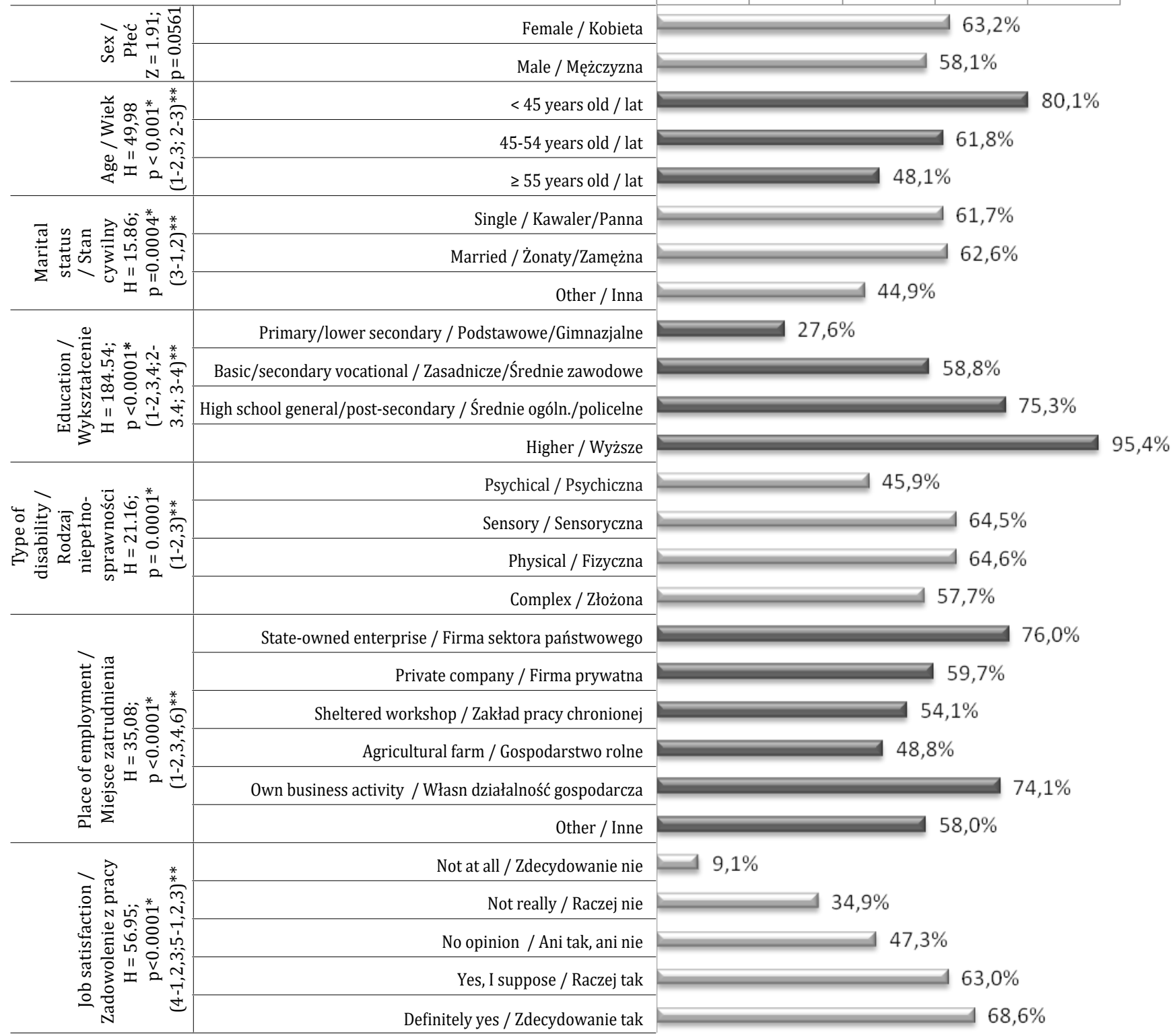

* - substantial variation at $\mathrm{p}<0.05$ / istotne zróżnicowanie przy $\mathrm{p}<0,05$

** - number of features, between which there is a statistically significant difference $(\mathrm{p}<0.05) / \mathrm{nr}$ cechy, pomiędzy którymi występuję istotna statystycznie różnica $(\mathrm{p}<0,05)$

Z - Mann-Whitney U-test value / Wartość testu U Manna-Whitneya;

H - Kruskal-Wallis H-test value / H -Wartość testu Kruskala-Wallisa

Figure 2. Computer usage by people with disabilities depending on their sex, age, marital status, education, type of disability, place of employment, job satisfaction

Rysunek 2. Korzystanie z komputerów przez osoby niepełnosprawne w zależności od płci, wieku, stanu cywilnego, wykształcenia, rodzaju niepełnosprawności, miejsca zatrudnienia, zadowolenia z pracy

Source: elaboration based on own research.

Źródło: opracowanie na podstawie badań własnych.

- $91.8 \%$ or in private enterprises - 91.1\%. The Internet is also popular among the vast majority of respondents working in sheltered workshops $85.6 \%$ and agricultural farms - 82.5\%. A significant percentage of computer users who are fully satisfied with their work, that is $92.4 \%$, are the Internet users. The common use of computers by the disabled ność gospodarczą 92,5\%, pracuje w przedsiębiorstwie państwowym - 91,8\% lub prywatnym - 91,1\%. Internet jest także popularny wśród zdecydowanej większości respondentów pracujących w zakładach pracy chronionej-85,6\% i gospodarstwach rolnych - 82,5\%. Znaczny odsetek, stanowiący 92,4\% użytkowników komputerów zdecydowanie zadowolonych z pracy to 
persons living in rural areas with respect to gender, age, marital status, education, type of disability, place of employment, job satisfaction, taking into account statistical differences between the features is presented in Table 3. użytkownicy Internetu. Powszechność wykorzystania Internetu przez osoby niepełnosprawne zamieszkałe na obszarach wiejskich z uwagi na płeć, wiek, stan cywilny, wykształcenie, rodzaj niepełnosprawności, miejsce zatrudnienia, zadowolenie z pracy z uwzględnieniem różnic statystycznych między cechami przedstawia tabela 3.

Table 3. The Internet usage by people with disabilities depending on sex, age, marital status, education, type of disability, place of employment, job satisfaction (the percentage among people using computers)

Tabela 3. Korzystanie z Internetu przez os oby niepełnosprawne w zależności od płci, wieku, stanu cywilnego, wykształcenia, rodzaju niepełnosprawności, miejsca zatrudnienia, zadowolenia z pracy (udział\% wśród osób korzystających z komputerów)

\begin{tabular}{|c|c|c|}
\hline \multirow{2}{*}{$\begin{array}{c}\text { Sex / Płeć } \\
Z=-0.54 ; p=0.5919\end{array}$} & Female / Kobieta & $89.2 \%$ \\
\hline & Male / Mężczyzna & $88.0 \%$ \\
\hline \multirow{3}{*}{$\begin{array}{c}\text { Age } / \text { Wiek } \\
\mathrm{H}=1.83 ; \mathrm{p}=0.3999\end{array}$} & $<45$ years old / lat & $91.2 \%$ \\
\hline & $45-54$ years old / lat & $87.5 \%$ \\
\hline & $\geq 55$ years old / lat & $90.1 \%$ \\
\hline \multirow{3}{*}{$\begin{array}{l}\text { Marital status / Stan cywilny } \\
\qquad \mathrm{H}=8.24 ; \mathrm{p}=0.0162^{*}\end{array}$} & Single / Kawaler/Panna & $83.6 \%$ \\
\hline & Married / Żonaty/Zamężna & $90.6 \%$ \\
\hline & Other / Inny & $83.3 \%$ \\
\hline \multirow{4}{*}{$\begin{array}{c}\text { Education / Wykształcenie } \\
\mathrm{H}=46.21 ; \mathrm{p}<0.0001^{*}\end{array}$} & Primary/lower secondary / Podstawowe/gimnazjalne ${ }^{2,3,4 * *}$ & $64.2 \%$ \\
\hline & Basic/secondary vocational / Zasadnicze/średnie zawodowe1 ${ }^{1 * *}$ & $87.3 \%$ \\
\hline & High school/post-secondary / Średnie ogóln./policealne ${ }^{1 * *}$ & $93.6 \%$ \\
\hline & Higher / Wyższe ${ }^{1 * *}$ & $97.2 \%$ \\
\hline \multirow{4}{*}{$\begin{array}{c}\text { Type of disability / Rodzaj } \\
\text { niepełnosprawności } \\
\mathrm{H}=27.06 ; \mathrm{p}<0.0001^{*}\end{array}$} & Psychical / Psychiczna ${ }^{3 * *}$ & $70.4 \%$ \\
\hline & Sensory / Sensoryczna & $91.0 \%$ \\
\hline & Physical / Fizyczna ${ }^{1 * *}$ & $91.3 \%$ \\
\hline & Complex / Złożona & $88.0 \%$ \\
\hline \multirow{6}{*}{$\begin{array}{l}\text { Place of employment } \\
\text { Miejsce zatrudnienia } \\
\mathrm{H}=8.73 ; \mathrm{p}=0.1205^{*}\end{array}$} & State-owned enterprise / Firma sektora państwowego & $91.8 \%$ \\
\hline & Private company / Firma prywatna & $91.1 \%$ \\
\hline & Sheltered workshop / Zakład pracy chronionej & $85.6 \%$ \\
\hline & Agricultural farm / Gospodarstwo rolne & $82.5 \%$ \\
\hline & Own business activity / Własna działalność gospodarcza & $92.5 \%$ \\
\hline & Other / Inne & $84.9 \%$ \\
\hline \multirow{5}{*}{$\begin{array}{c}\text { Job satisfaction } / \\
\text { Zadowolenie z pracy } \\
\mathrm{H}=10.11 ; \mathrm{p}=0.0387^{*}\end{array}$} & Not at all / Zdecydowanie nie & $100 \%$ \\
\hline & Not really / Raczej nie & $90.9 \%$ \\
\hline & No opinion / Ani tak, ani nie & $80.7 \%$ \\
\hline & Yes, I suppose / Raczej tak & $87.6 \%$ \\
\hline & Definitely yes / Zdecydowanie tak & $92.4 \%$ \\
\hline
\end{tabular}

* - substantial variation at $\mathrm{p}<0.05$ / istotne zróżnicowanie przy $\mathrm{p}<0,05$

** - number of features, between which there is a statistically significant difference $(\mathrm{p}<0.05) /$ nr cechy, pomiędzy którymi występuję istotna statystycznie różnica $(p<0,05)$

Z - Mann-Whitney U-test value / Wartość testu U Manna-Whitneya;

H - Kruskal-Wallis H-test value / Wartość testu Kruskala-Wallisa

Source: elaboration based on own research.

Źródło: opracowanie na podstawie badań własnych.

During the research, the percentage of people with disabilities living in rural areas and using the Internet for professional purposes was determined. The percentage between both sexes is very similar here. In case of women, it is $32.4 \%$, and for men, it is $32.8 \%$. The highest percentage of the Internet use for professional purposes is among people in the age group up to $45-37.1 \%$. Every third respondent in the age group 45-54 using the Internet uses the network for professional purposes. In the age group 54+ it is $26.2 \%$. The highest percentage of respondents being singles, used computer network for their professional work - 36.4\%. Among married couples $-32.0 \%$, and among widows and widowers - $28 \%$. The Internet was most often used for professional
W czasie badania określono jaka część osób niepełnosprawnych zamieszkująca obszary wiejskie korzystająca z Internetu wykorzystuje go do celów zawodowych. Odsetek wśród obu płci jest tu bardzo zbliżony. W przypadku kobiet wynosi 32,4\%, a mężczyzn 32,8\%. Największy udział w wykorzystaniu Internetu do celów zawodowych mają osoby w grupie wiekowej poniżej 45 roku życia - 37,1\%. Co trzeci respondent używający Internetu w wieku 45-54 lata korzysta z sieci w celu wykonywania pracy. W wieku 54 lata i więcej takich osób jest 26,2\%. Największy odsetek respondentów będących kawalerami lub pannami używało sieci komputerowej do pracy zawodowej - 36,4\%. Osób w związkach małżeńskich było 32,0\%, a wdów i wdowców $28 \%$. Internet do pracy najczęściej wyko- 
purposes by disabled persons with higher education - $67.1 \%$ of respondents using the Internet for various purposes. A lower percentage was recorded in the group of people with general high school and postsecondary education - $39.7 \%$, basic and secondary vocational education- $21.0 \%$, and primary and lower secondary education - 5.9\%. Among the Internet users, about one third of the respondents with physical disability $-35.2 \%$, sensory disability - $32.1 \%$, and complex disability - $31.3 \%$ uses it for professional purposes. In the group of people with mental disability this percentage is lower and amounts to $16.0 \%$. More than half of the Internet users conducting their own business activity uses it for professional purposes - $56.8 \%$. The same applies to the respondents employed in state-owned enterprises - $49,7 \%$. In case of persons employed in private companies, $34.2 \%$ of the respondents use the Internet for professional purposes. In case of the employees of sheltered workshops, this percentage is $26.9 \%$, and in case of farm workers it is $15.2 \%$. rzystywały osoby niepełnosprawne z wykształceniem wyższym - 67,1\% respondentów korzystających z Internetu do różnych celów. Mniejszy udział zanotowano w grupie osób z wykształceniem średnim ogólnym i policealnym - 39,7\%, zasadniczym i średnim zawodowym - 21,0\% oraz podstawowym i gimnazjalnym 5,9\%. Wśród wykorzystujących Internet, około jedna trzecia respondentów z niepełnosprawnością fizyczną - 35,2\%, sensoryczną - 32,1\%, złożoną - 31,3\% używa go do celów zawodowych. W grupie osób z niepełnosprawnością psychiczną odsetek ten jest niższy i wynosi $16,0 \%$. Ponad połowa użytkowników Internetu, prowadzących własną działalność gospodarczą wykorzystuje go do pracy - 56,8\%. Tym samym działaniem charakteryzuje się blisko połowa $-49,7 \%$ respondentów pracujących w przedsiębiorstwach państwowych. $\mathrm{W}$ przypadku zatrudnionych $\mathrm{w}$ firmach prywatnych Internetu do celów zawodowych używa 34,2\% osób korzystających ogólnie z Internetu. W przypadku pracowników zakładów pracy chronionej ten odsetek to $26,9 \%$, a pracowników gospodarstw rolnych $15,2 \%$.

Table 4. The Internet usage by people with disabilities depending on sex, age, marital status, education, type of disability, place of employment, job satisfaction (the percentage among people using computers)

Tabela 4. Korzystanie z Internetu w celu wykonywania pracy w zależności od płci, wieku, stanu cywilnego, wykształcenia, rodzaju niepełnosprawności, miejsca zatrudnienia, zadowolenia z pracy (udział\% wśród osób korzystających z Internetu)

\begin{tabular}{|c|c|c|}
\hline \multirow{2}{*}{$\begin{array}{c}\text { Sex / Płeć } \\
\mathrm{Z}=0.11 ; \mathrm{p}=0.9120\end{array}$} & Female / Kobieta & $32.4 \%$ \\
\hline & Male / Mężczyzna & $32.8 \%$ \\
\hline \multirow{3}{*}{$\begin{array}{c}\text { Age } / \text { Wiek } \\
\mathrm{H}=3.95 ; \mathrm{p}=0.1390\end{array}$} & $<45$ years old / lat & $37.1 \%$ \\
\hline & $45-54$ years old / lat & $33.3 \%$ \\
\hline & $\geq 55$ years old / lat & $26.2 \%$ \\
\hline \multirow{3}{*}{$\begin{array}{l}\text { Marital status / Stan cywilny } \\
\qquad \mathrm{H}=1.50 ; \mathrm{p}=0.4718\end{array}$} & Single / Kawaler/Panna & $36.4 \%$ \\
\hline & Married / Żonaty/Zamężna & $32.0 \%$ \\
\hline & Other / Inny & $28.0 \%$ \\
\hline \multirow{4}{*}{$\begin{array}{c}\text { Education / Wykształcenie } \\
\mathrm{H}=115.57 ; \mathrm{p}<0.0001^{*}\end{array}$} & Primary/lower secondary / Podstawowe/gimnazjalne ${ }^{2,3,4 * *}$ & $5.9 \%$ \\
\hline & Basic/secondary vocational / Zasadnicze/średnie zawodowe1 ${ }^{1^{* *}}$ & $21.0 \%$ \\
\hline & High school/post-secondary / Średnie ogóln./policealne ${ }^{1 * *}$ & $39.7 \%$ \\
\hline & Higher / Wyższe ${ }^{1 * *}$ & $67.1 \%$ \\
\hline \multirow{4}{*}{$\begin{array}{c}\text { Type of disability / } \\
\text { Rodzaj niepełnosprawności } \\
\mathrm{H}=7.67 ; \mathrm{p}=0.0532\end{array}$} & Psychical / Psychiczna ${ }^{3 * *}$ & $16.0 \%$ \\
\hline & Sensory / Sensoryczna & $32.1 \%$ \\
\hline & Physical / Fizyczna ${ }^{1 * *}$ & $35.2 \%$ \\
\hline & Complex / Złożona & $31.3 \%$ \\
\hline \multirow{6}{*}{$\begin{array}{l}\text { Place of employment / } \\
\text { Miejsce zatrudnienia } \\
\mathrm{H}=54,06 ; \mathrm{p}<0.0001^{*}\end{array}$} & State-owned enterprise / Firma sektora państwowego & $49.7 \%$ \\
\hline & Private company / Firma prywatna & $34.2 \%$ \\
\hline & Sheltered workshop / Zakład pracy chronionej & $26.9 \%$ \\
\hline & Agricultural farm / Gospodarstwo rolne & $15.2 \%$ \\
\hline & Own business activity / Własna działalność gospodarcza & $56.8 \%$ \\
\hline & Other / Inne & $14.7 \%$ \\
\hline \multirow{5}{*}{$\begin{array}{c}\text { Job satisfaction } / \\
\text { Zadowolenie z pracy } \\
\mathrm{H}=18.98 ; \mathrm{p}=0.0008^{*}\end{array}$} & Not at all / Zdecydowanie nie & $0.0 \%$ \\
\hline & Not really / Raczej nie & $15.0 \%$ \\
\hline & No opinion / Ani tak, ani nie & $18.3 \%$ \\
\hline & Yes, I suppose / Raczej tak & $30.4 \%$ \\
\hline & Definitely yes / Zdecydowanie tak & $41.0 \%$ \\
\hline
\end{tabular}

* - substantial variation at $\mathrm{p}<0.05$ / istotne zróżnicowanie przy $\mathrm{p}<0,05$

** - number of features between which there is a statistically significant difference $(\mathrm{p}<0.05) /$ nr cechy, pomiędzy którymi występuję istotna statystycznie różnica $(\mathrm{p}<0,05)$

Z - Mann-Whitney U-test value / Wartość testu U Manna-Whitneya;

h - Kruskal-Wallis H-test value / Wartość testu Kruskala-Wallisa

Source: elaboration based on own research.

Źródło: opracowanie na podstawie badań własnych. 
Taking into account job satisfaction, in the group of satisfied people the Internet is used for professional purposes by $41.0 \%$ of respondents. Table 4 describes the use of the Internet for professional purposes, taking into account statistical differences between the distinguished features.

\section{Conclusions}

The Internet, like all IT technologies, is successfully used by the disabled persons and their families as an invaluable source of information, reference and a tool for practicing many necessary skills. People with disabilities can meet people in a similar life situation and with similar interests through the Internet (Bartnikowska Żyta 2006). Nowadays, the Internet is also an important tool for initiating professional activity by people with disabilities.

Majority of the disabled persons who were professionally active and who participated in the research were computer users. Almost all people in this group use the Internet resources and its functions. The Web, however, is used for professional purposes only by every third Internet user, which indicates great development opportunities for the use of this means of communication in the future. It is worth making an effort related to the wider use of computers, the Internet and other assistive devices by people with disabilities, including those living in rural areas. Activation in this sphere will bring many economic benefits. If people with disabilities enter the labour market it will result in changes in the market due to competitiveness, strong motivation of the disabled persons, and loyalty towards an employer. As a result of switch to outsourcing and working at home (including people with disabilities), which is possible in a number of industries due to their high level of computerisation, the necessity to maintain standard (that is more expensive) workplaces will no longer be required. Easier access to enhancing professional qualifications and increase in the number of working people with disabilities can lead to the reduction in the number of pensions and benefits paid,

improvement of the system of the disability equipment co-financing (including people having severe disabilities or being in a more difficult life situation) and increase in the number of people paying taxes. (http://www.academia.edu/2245263/ WSPARCIE_TELEINFORMATYCZNE_AKTYWIZACJI_ EDUKACYJNEJ_I_ZAWODOWEJ_OS $\%$ C 3\%93B_ NIEPE\%C5\%81NOSPRAWNYCH_PROPOZYCJA_ ROZWI\%C4\%84ZANIA, access: 07.01.2018).

It is not surprising that computer is a technical device more often used by young people with disabilities. This regularity also applies to nondisabled people. Age in case of the disabled persons is not the factor influencing their use of the Internet. Respondents from all age groups equally often enjoyed the benefits of the Internet. Research has shown that both computer and the Internet are particularly important tools in the professional
Biorąc pod uwagę zadowolenie z pracy w grupie osób zdecydowanie zadowolonych $41,0 \%$ wykorzystuje go do celów zawodowych. Wykorzystanie Internetu do celów zawodowych z uwzględnieniem różnic statystycznych między wyróżnionymi cechami przedstawia tabela 4.

\section{Podsumowanie i wnioski}

Internet, podobnie jak wszelkie techniki informatyczne, z powodzeniem wykorzystywany jest przez osoby niepełnosprawne i ich rodziny jako nieocenione źródło informacji, środek poglądowy oraz narzędzie do ćwiczenia wielu niezbędnych umiejętności. W Sieci osoby niepełnosprawne mogą nawiązywać kontakt z ludźmi o podobnej sytuacji życiowej i zainteresowaniach (Bartnikowska Żyta 2006). Obecnie Internet to także ważne narzędzie umożliwiające podjęcie aktywności zawodowej przez osoby niepełnosprawne.

Większość osób niepełnosprawnych, czynnych zawodowo, które uczestniczyły w badaniu korzysta z komputera. Prawie wszystkie osoby z tej grupy wykorzystują zasoby i funkcje Internetu. Ta Sieć jest jednak wykorzystywana do czynności zawodowych zaledwie przez trzecią część uży tkowników Internetu, co wskazuje na duże możliwości rozwojowe w wykorzystaniu tego środka komunikacji w przyszłości. Warto podjąć wysiłek związany z szerszym wykorzystaniem komputerów i Internetu oraz innych urządzeń wspomagających (ang. assistive devices) przez osoby niepełnosprawne, także te zamieszkałe na obszarach wiejskich. Aktywizacja w tym wymiarze niesie to ze sobą wiele korzyści ekonomicznych. Wejście na rynek pracy osób niepełnosprawnych spowoduje zmiany na rynku pracownika i pracodawcy poprzez konkurencyjność, silną motywację osób niepełnosprawnych, lojalność wobec pracodawcy. Przejście na outsourcing i pracę $\mathrm{w}$ domu (w tym osób niepełnosprawnych), możliwy w szeregu branż ze względu na ich silną informatyzację spowoduje brak konieczności utrzymania standardowych (czyli droższych) miejsc pracy. Ułatwiony dostęp do podwyższania kwalifikacji oraz zwiększanie się liczby zarobkujących niepełnosprawnych może przełożyć się na zmniejszenie ilości wypłacanych rent i zasiłków,

poprawienie się struktury wypłacanych dofinansowań do sprzętu dla niepełnosprawnych (m.in. na rzecz osób z cięższymi deficytami lub w trudniejszej sytuacji rodzinnej) oraz zwiększenie się liczby osób płacących podatki. (http://www.academia.edu/2245263/ WSPARCIE_TELEINFORMATYCZNE_AKTYWIZACJI_ EDUKACYJNEJ_I_ZAWODOWEJ_OS\%C3\%93B_NIEPE\%C5\%81NOSPRAWNYCH_PROPOZYCJA_ROZWI\%C4\%84ZANIA, dostęp: 07.01.2018).

Co nie zaskakuje, komputer jest urządzeniem technicznym częściej wykorzystywanym przez młode osoby niepełnosprawne. Prawidłowość ta dotyczy także osób pełnosprawnych. Wiek w przypadku niepełnosprawnych nie wpływa na skłonność do wykorzystania Internetu. Respondenci ze wszystkich kategorii wiekowych równie często korzystali z jego dobrodziejstw. Badania dowiodły, że komputer i Internet to narzędzia szczególnie istotne $w$ aktywizacji zawodowej osób niepełnosprawnych zamieszkałych 
activation of the disabled persons with higher education living in rural areas. Among such persons the highest percentage of the respondents declared the use of the computer devices and IT technology. Computer and the Internet are most often used by the disabled persons with physical, sensory and complex disabilities. It applies to a lesser extent to people with mental disabilities. It results mainly from the type of disability and the lack of available technical and IT solutions for people with this type of disability. A computer with an internet connection is an invaluable working tool for people, including those with disabilities, who conduct their business activity in rural and urban-rural communes. They together with people employed in state-owned enterprises most often use these technological solutions.

Due to the constant development of the Internet and virtual communities, it is necessary to counteract the digital exclusion of the disabled persons. Changes should take place in terms of greater availability of equipment and internet connection for the disabled persons, as well as a greater understanding of the needs of people with disabilities by companies and organisations displaying information on websites. Such changes should take place both on the legal and cultural grounds - the disabled persons constitute a separate group of the Internet users, but not so much in terms of needs but perception possibilities (Dejnak 2012). It is also important to make the disabled persons aware of the benefits offered by modern IT solutions. A high degree of responsibility here rests with family, friends, employers, local government units as well as with institutions and organisations performing social functions concerning the methods of promoting and teaching how to use computer and the Internet resources. na obszarach wiejskich z wykształceniem wyższym. To one, w swojej kategorii wykształcenia procentowo najczęściej deklarowały wykorzystywanie opisywanych urządzeń i technologii informatycznej. Z komputera i Internetu najczęściej korzystają osoby niepełnosprawne z dysfunkcją fizyczną, sensoryczną i złożoną. W mniejszym stopniu przez osoby z niepełnosprawnością psychiczną. Wynika to przede wszystkim z rodzaju niepełnosprawności oraz z braku dostępnych rozwiązań technicznych i informatycznych dla tego rodzaju niepełnosprawności. Komputer z łączem internetowym to nieocenione narzędzie pracy osób przedsiębiorczych, także tych niepełnosprawnych, którzy prowadzą swoją działalność gospodarczą na terenie gmin wiejskich i miejsko-wiejskich. To oni wraz z osobami zatrudnionymi w przedsiębiorstwach sektora państwowego najczęściej korzystają z tych rozwiązań technicznych.

W związku ze stałym rozwojem Internetu oraz społeczności wirtualnych niezbędne jest przeciwdziałanie cyfrowemu wykluczeniu osób niepełnosprawnych. Zmiany powinny nastąpić zarówno w aspekcie większej dostępności do sprzętu oraz podłączenia do Internetu dla osób niepełnosprawnych, jak i większego zrozumienia potrzeb osób z dysfunkcjami przez firmy i organizacje, prezentujące informacje w serwisach internetowych. Zmiany takie powinny nastąpić zarówno na podłożu prawnym, jak i kulturowym - niepełnosprawni stanowią bowiem odrębną grupę uży tkowników Internetu, jednak nie tyle pod względem potrzeb ile możliwości percepcyjnych (Dejnaka 2012). Ważne jest także uświadomienie samym osobom niepełnosprawnym korzyści wynikających z nowoczesnych rozwiązań teleinformatycznych. Tu szczególnie duża odpowiedzialność w propagowaniu i nauce wykorzystania komputera i Internetu spoczywa na rodzinie, znajomych, pracodawcach, jednostkach samorządu terytorialnego oraz instytucjach i organizacjach realizujących funkcje społeczne.

\section{References / Literatura:}

1. Bartnikowska U., Żyta A. (2006), Internet w procesie edukacji i rehabilitacji osób głuchoniewidomych. Szkoła Specjalna, t. LXVII, nr 5 (237), s. 338.

2. Dejnaka A. (2012), Internet bez barier - accessibility oraz usability a potrzeby osób niepełnosprawnych. Niepełnosprawność zagadnienia, problemy, rozwiązania, t.2, nr 3, s. 41.

3. Garbat M. (2013), Aktywizacja zawodowa osób z niepełnosprawnościq̨. Uniwersytet Zielonogórski, Zielona Góra.

4. Jan Paweł II (1987), Laborem Exercens. Tekst i komentarze, Lublin.

5. Magnuszewska-Otulak G. (2009), Uczestnictwo osób niepełnosprawnych w życiu społecznym. Instytut Polityki Społecznej Uniwersytetu Warszawskiego, Warszawa.

6. Mikołajewska E., Mikołajewski D. (2018), Wsparcie teleinformatyczne aktywizacji edukacyjnej i zawodowej osób niepełnosprawnych - propozycja rozwiqzania, http://www.academia.edu/2245263/WSPARCIE_TELEINFORMATYCZNE_AKTYWIZACJI_EDUKACYJNEJ_I_ZAWODOWEJ_OS\%C3\%93B_NIEPE\%C5\%81NOSPRAWNYCH_PROPOZYCJA_ROZWI\%C4\%84ZANIA, (data dostępu: 07.01.2018).

7. Ochonczenko H. (2004), Sytuacja na rynku pracy osób niepełnosprawnych $w$ dobie zmian społecznych i gospodarczych $w$ Polsce, W: J. Bąbka (red.), Człowiek niepełnosprawny w różnych fazach życia. Wydawnictwo Akademickie „Żak”, Warszawa, s. 225.

8. Olszewski S., Parys K., Trojańska M. (2012), Przestrzenie życia osób z niepełnosprawnością, Wyd. Uniwersytetu Pedagogicznego w Krakowie, Kraków, s. 161.

9. Szczupał B. (2012), Aktywizacja zawodowa i zatrudnienie osób z niepełnosprawnością na współczesnym rynku pracy - wybrane uwarunkowania i rozwiqzania praktyczne, W: D. Tomczyszyn, W. Romanowicz (red.) Aktywność zawodowa osób z niepełnosprawnościq. Wyd. Państwowej Szkoły Wyższej im. Papieża Jana Pawła II w Białej Podlaskiej, Biała Podlaska, s. 151.

10. Szczupał B. (2006), Wybrane aspekty poczucia jakości życia bezrobotnych osób niepełnosprawnych. W: Z. Palak (red). Jakość życia osób niepełnosprawnych i nieprzystosowanych społecznie, Lublin, s. 187. 
11. Wołosiuk B. (2012), Kształcenie zawodowe osób z niepełnosprawnościq, W: B. Wołosiuk, M. Nowak (red.), Kształcenie zawodowe i ustawiczne a potrzeba rynku. Wyd. Państwowej Szkoły Wyższej im. Papieża Jana Pawła II w Białej Podlaskiej, Biała Podlaska, s. 239.

12. Wójcik M. (2008), Aktywność ekonomiczna osób niepełnosprawnych, W: B. Skrętowicz i M. Komorowska (red.), Osoby niepełnosprawne w społeczeństwie polskim okresu transformacji. Wyd. UMCS w Lublinie, Lublin, s. 29.

13. http://www.niepelnosprawni.gov.pl/index.php?c=page\&id=78\&print=1, (data dostępu: 27.12.2017).

14. http://www.niepelnosprawni.gov.pl/index.php?c=page\&id=80\&print=1, (data dostępu: 27.12.2017). 